\title{
AN ASSESSMENT OF THE VALUE OF PASTORAL DEVELOPMENT IN NORTHLAND
}

\author{
A. T. G. MCArThur \\ Senior Lecturer in Rural Education, Lincoln College \\ K. T. SANDERSON \\ Research Economist, A.E.R.U., Lincoln College
}

\section{INTRODUCTION}

THIS PAPER presents the results of an economic study of farm development in Northland.* In this study, records were collected of 32 dairy farm case histories which had increased butterfat production by $105 \%$ in an average of 6 years, and 18 sheep farm case histories for which wool production increased $116 \%$ over a 7 -year period. Also included are data supplied by the Lands and Survey Department on the economic outcome of two land development blocks. Before presentation of these results of phenomenal technical progress, some points about the meaning of value of development require clarification.

It is one thing to specify the outcome of a course of action, but it is quite another thing to place a value on it. Each specialist training tends to inculcate its students with a specific set of values. A soil conservator feels just as badly about a slipping hill-face as a veterinarian feels about a cow with tuberculosis, a disease he wants to eradicate at all costs. Agronomists feel enthusiastic about prize-winning pastures established on gumland soils, and animal husbandmen like to see sleek high-plane animals. While farm business specialists are more likely to look at the farm as a system, they, too, occasionally fall into the same ethnocentric trap as the others. For instance, they tend to imagine that farmers have the same value judgements as they have. Some exhort farmers to look at the farm as a businessmen does, and urge them to maximize their return on capital. This, of course, begs the question as to whether

\footnotetext{
* This research was generously funded by the Commercial Rank of Australia to mark their 100th Anniversary.
} 
businessmen actually aim at getting the best return on their capital and mere exhortation does not justify this set of values.

In this paper, attention is focused on the cash costs and benefits of development and their valuation by economic methods. Nevertheless, the deficiencies of this approach are recognized, because cash costs ani benefits are only one dimension of the outcome of development and the method used for valuing this outcome makes assumptions about the values of the farmer and society.

There are other dimensions of the outcome as well as cash. There is the risk associated with development and the sense of achievement when it is completed, to mention but two. The relative importance of these dimensions depends on the individual and his social background. Valuation within any dimension also varies from individual to individual. As Galbraith (1966) has pointed out, the Scotch Canadian farming community which nurtured him had a higher negative value for costs than they had for gains. In other words, while they liked receiving money they disliked spending it even more.

\section{METHOD OF ANALYSIS}

The Appendix to this paper sets out the details of the method of analysis of the data collected from case history farms. Technical information was collected from these farmers about the inputs and outputs of their farms before, during and after development. They were extremely helpful and often the entire family labour force was mobilized to retrieve the records. It was not possible to account for all the inputs in technical terms and there was a residual of farm expenses expressed in dollars.

The technical items were converted to cash by multiplying by constant prices using 1965-6 values." By holding prices constant, the cash outcome reflected changes due to development and was not confounded by price fluctuations.

The analysis aimed at finding the extra cash costs and cash benefits from development compared with a "before development" position. The value of development compared with "standing put" was estimated. Table 1 gives a simpli-

\footnotetext{
* All calculations were handled by the University of Canterbury TBM 1620 and the Lincoln College IBM 1130 computers.
} 
TABLE 1: EXTRA COSTS AND BENEFITS

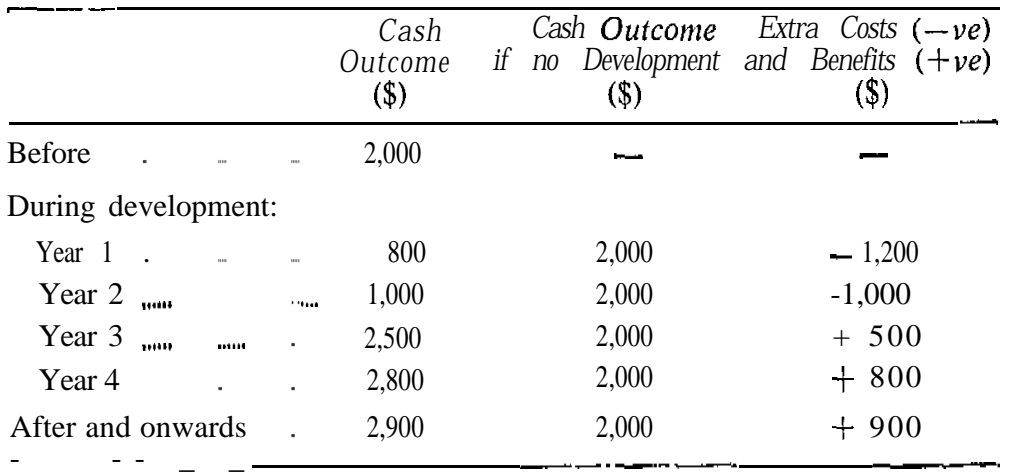

fied hypothetical illustration of the method of determining the extra costs and benefits of development.

While real data were used for the analysis, it was often necessary to use estimates for the "before" and "after" situations because most of the case histories involved a history of continuous development rather than the stop-gostop situation illustrated by Table 1 .

The kind of costs included in the estimation of the cash outcome depends upon the purpose for which the analysis is done. The data presented here have been analysed from the national point of view, which excludes tax, and from the individual point of view, which includes it. Taxation has a major bearing on the value of development.

The cash outcome in terms of a stream of extra costs and benefits was valued by determining its equivalent as a lump sum payment today. For instance, the stream of costs, and benefits in Table 1 are equivalent to a lump sum payment now, or present value today, of $\$ 10,900$. This particular value assumes that farmers discount future cash outcomes at $6 \%$ a year. It assumes that a farmer considers it immaterial whether he gains $\$ 500$ today or has to wait 12 years for $\$ 1,000$ because he knows $\$ 500$ invested today will grow into $\$ 1,000$ in 12 years' time by compound interest.

A nother useful measure calculated was the internal rate of return. This is the break-even interest rate at which the costs equal the benefits. For the data in Table 1, the internal rate is $31 \%$. Thus, if a decision-maker is uncertain of the discount rate which measures his disutility for time, he may say "I am sure I discount at a lower rate than this so the present value of the project must be positive". 
The "present value/ present value of the cost" is 5.4 for the data in Table 1. This effectiveness/ cost ratio is a method of assigning priorities to projects where it is possible to have more than one project in an overall plan including many projects and where the decision is limited by the funds to meet initial costs. The appropriate measure must be used for each circumstance.

\section{SOURCE OF DATA AND RESULTS}

Clients of Northland advisory officers provided the technical and financial information needed for this investigation. Advisers were asked to suggest farmers who had made rapid technical progress over recent years and who had used methods considered worth emulating by others in similar conditions. Nearly all the farmers who fell into this class made their records available.

\section{DAiRY FARM CASE Histories}

The case histories of 32 dairy farms were used. These farms made butterfat gains at a compounded rate of $12.6 \%$ a year over 6 years - the mean development period studied.

Heavier stocking combined with heavier manuring were the key factors in raising production, together with the appropriate changes in management.

Stocking in terms of ewe equivalents on the 32 dairy farms went up $9 \%$ a year. The ratio of fertilizer per ewe equivalent rose a little in the initial years of development as Table 2 shows.

TABLE 2: FERTILIZER ON DAIRYFARMS

\begin{tabular}{|c|c|c|c|c|c|c|c|c|c|}
\hline \multicolumn{10}{|c|}{ Cwt/Ewe Equivalent } \\
\hline Before ( & $\operatorname{ar} 0)$ & $-\cdots$ & $\ldots$ & $\ldots$ & $\ldots \ldots$ & $\ldots$ & $\ldots$ & $\ldots$ & 0.7 \\
\hline \multicolumn{10}{|c|}{ During development: } \\
\hline Year 1 & ...." & $\ldots$ & $\ldots$ & $\ldots$ & ..... & $\ldots$ & $\ldots$. & & 1.0 \\
\hline Year 2 & ..... & $\ldots$ & $\ldots$ & $\ldots$ & $\ldots$ & $\ldots$ & & $\ldots .$. & 1.1 \\
\hline Year 3 & ..." & $\ldots$ & $\ldots$ & $\ldots$ & ..... & $\ldots$ & $\ldots$ & $\ldots$ & 1.15 \\
\hline Year 4 & $\ldots$ & $\ldots$ & $\ldots$ & $\ldots$ & $\ldots$ & $\ldots$ & $\ldots$ & $\ldots$ & 1.0 \\
\hline Year 5 & $\ldots$ & ..... & $\ldots$ & $\ldots$ & $\ldots$ & $\ldots$ & $\ldots$ & $\ldots$ & 1.0 \\
\hline Year 6 & $\ldots . .$. & $\ldots$ & $\ldots$ & $\ldots$ & $\ldots \ldots$ & $\ldots$ & $\ldots$ & ...... & 0.95 \\
\hline
\end{tabular}


On the wetter soils, management to minimize pugging played a major role in increased output. In one extreme case, the farmer built a cubicle-type barn, raised his cow numbers to over one per acre on 120 acres of hill country and developed his run-off to make hay, finish store lambs and run his dry stock. Most farmers had calved their cows later and adopted some pugging-reducing system such as the split-herd winter system. In four cases, sawdust pads played a useful role in keeping stock out of the mud.

More than half the case history farmers constructed herringbone sheds with round yards attached (18 out of 32) which allowed them to milk extra cows without increasing "wages paid" proportionally. Other "capital expenditures" which contributed to output per acre and per labour unit were races, fencing, drainage schemes, rotary slashers for dealing with gorse and rushes, and gear for pasture conservation. On small farms, extra land was bought or broken in.

In the dairy farm case studies, butterfat was valued at $\$ 0.33$ per Ib sold as wholemilk for 1965-6. Table 3 shows the mean marginal cash outcome per farm and also the three valuing measures.

The results in Table 3 show that the nation can be expected to benefit by nearly $\$ 4,000$ a year per farm once development is complete and the individual farmers can expect an extra income of $\$ 2,400$, the difference being due to taxation. All the measures of value are very healthy. In interpreting such a high internal rate as $55 \%$, it must be

TABLE 3: MEAN DAIRY FARM DEVELOPMENT RESULTS $(n=32)$

\begin{tabular}{|c|c|c|c|c|c|c|c|c|c|}
\hline & & & & & & & & $\begin{array}{c}\text { National Point } \\
\text { of View }\end{array}$ & $\begin{array}{l}\text { Individual Point } \\
\text { of View }\end{array}$ \\
\hline \multicolumn{10}{|c|}{ Extra cash outcome (\$) : } \\
\hline Year & 1 & $\ldots . .$. & $\ldots$ & ........ & & $\ldots$. & $\ldots$ & $-1,658$ & $-1,612$ \\
\hline Year & 2 & $\ldots . .$. & $\ldots$ & ........ & & $\ldots . .$. & $\ldots . .$. & +78 & -134 \\
\hline Year & 3 & $\ldots . .$. & $\ldots$ & ........ & & $\ldots . .$. & $\ldots . . .$. & +346 & +100 \\
\hline Year & 4 & $\ldots . .$. & $\ldots . .$. & ........ & & ....... & $\ldots$ & $+1,050$ & +442 \\
\hline Year & & $\ldots$ & $\ldots$ & ...... & & $\ldots .$. & $\ldots$ & $+1,048$ & +144 \\
\hline Year & 6 & $\ldots . .$. & $\ldots . .$. & ........ & & $\ldots$ & $\ldots$ & $+2,620$ & $+1,420$ \\
\hline Year & 7 & $\ldots . . .$. & $\ldots . .$. & ....... & & $\ldots . .$. & $\ldots$ & $+3,608$ & $+2,238$ \\
\hline Year & 8 & $\ldots . . .$. & $\ldots$ & ...... & & .......... & $\ldots$ & $+3,712$ & $+2,292$ \\
\hline Year & 9 & $\ldots . .$. & $\ldots$ & ...... & & $\ldots . .$. & $\ldots$ & $+3,764$ & 12,330 \\
\hline Year & $>9$ & $\ldots$ & $\ldots .$. & ....... & & $\ldots . .$. & $\ldots$ & $+3,928$ & $+2,512$ \\
\hline Present & value & e at & $6 \%$ & ....... & & $\ldots$ & $\ldots$ & $\$ 48,000$ & $\$ 28,200$ \\
\hline Internal & rate & of & return & 1 & & .......... & $\ldots$ & $55.8 \%$ & $38.6 \%$ \\
\hline Present & value & le/Pre & ent $y$ & value & of & costs & $\ldots$ & 30.7 & 17.2 \\
\hline
\end{tabular}


TABLE 4: FERTILJZER ON SHEEP FARMS

\begin{tabular}{|c|c|c|c|c|c|c|c|c|c|}
\hline & & & & & & & & \multicolumn{2}{|c|}{ Cwt/Ewe Equivalent } \\
\hline Before & ar 0 ) & & '"' & . & . & r. & & . & 0.6 \\
\hline \multicolumn{10}{|c|}{ During development: } \\
\hline Year 1 & 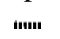 & "m!" & & & $\cdot$ & .'. & . & . & 0.9 \\
\hline Year 2 & "mi" & $\ldots . . . \cdot$ & . & . & $\cdot \ldots$ & . & - & -" & 1.0 \\
\hline Year 3 & & . & In!m & & . & 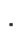 & m.m. & . & 0.7 \\
\hline Year 4 & "n!m & & ."':n & . & . . & . & . & . & 0.8 \\
\hline Year 5 & . & . & ....... & & & .... & $\ldots$ & - & 0.7 \\
\hline Year 6 & $\ldots$ & ........ & . & & & & . & $\ldots$ & 0.7 \\
\hline
\end{tabular}

appreciated that farm development involves more than investment ; it involves a total change in management combined with investment, It is this combination which results in such a high internal rate of return and value/ cost ratio.

\section{SHEEP FARM CASE Histories}

The 18 sheep farm case histories showed spectacular increases, too. Wool sales rose $12 \%$ a year compounded. or $116 \%$ over the 7-year period.

The Northland sheep farms studied were classified as store sheep farms. The farmers reared their own replacements except when their rate of development forced them to buy stock. They sold their wether lambs as either stores for winter fattening for the Auckland market or as fat lambs for export. In either event, the price was much the same. The case history farms had developed by increasing ewe and cattle numbers at much the same rate.

The basic method for increasing production was heavier stocking combined with heavier manuring. Table 4 shows that, as with the dairy farms, use of fertilizer per ewe equivalent rises in the critical early years and falls back to the initial ratio later.

The quality of the manure was a factor on sheep farms, there being a change from the use of straight superphosphate to molybdic and potassic superphosphate where appropriate. Topdressing with lime contributed in some cases.

Improved subdivision, both from a grazing management and a labour saving point of view, also helped progress on the case history sheep farms.

Table 5 shows the mean sheep farm development results of 17 case histories. The output prices used were $\$ 0.30$ for wool on a net price clear of selling costs, $\$ 4.4$ for fat lambs and $\$ 30.00$ for calves. The wool prices seem a little overestimated by today's level of pessimism. 
TABLE 5: MEAN SHEEP FARM DEVELOPMENT RESULTS $(n=17)$

\begin{tabular}{|c|c|c|c|c|c|c|c|}
\hline & & & & & & $\begin{array}{l}\text { National Point } \\
\text { of View }\end{array}$ & $\begin{array}{c}\text { Individual Point } \\
\text { of View }\end{array}$ \\
\hline \multicolumn{8}{|c|}{ Extra cash outcome $(\$)$ : } \\
\hline Year 1 & ........ & ....... & & $\ldots$ & $\ldots$ & $-5,404$ & $-5,042$ \\
\hline Year 2 & $\ldots$ & $\ldots$ & $\ldots$ & $\ldots$ & $\ldots$ & $-4,336$ & $-4,234$ \\
\hline Year 3 & ........... & $\ldots \ldots$ & $\ldots$. & $\ldots$ & $\ldots$ & $-3,230$ & -3.578 \\
\hline Year 4 & $\ldots$ & $\ldots$ & ..." & $\ldots$ & $\ldots$ & $-1,050$ & $-1,558$ \\
\hline Year 5 & ...... & ....." & $\ldots$ & $\ldots$ & $\ldots$ & $+2,259$ & +990 \\
\hline Year 6 & ...... & $\ldots$ & $\ldots$ & $\ldots$ & $\ldots$ & +578 & - 1,008 \\
\hline Year 7 & $\ldots$ & $\ldots . .$. & $\ldots$ & $\ldots$ & $\ldots$ & $+3,040$ & +926 \\
\hline Year 8 & $\ldots \ldots$ & $\ldots$ & $\ldots$ & $\ldots . .$. & $\ldots$ & $+4,754$ & $+2,276$ \\
\hline Year 9 & $\ldots$ & $\ldots$ & $\ldots$ & $\ldots$ & $\ldots$ & $+5,278$ & $+2,682$ \\
\hline Year $>9$ & $\ldots$ & $\ldots$ & $\ldots$ & $\ldots$ & $\ldots$ & $+5,558$ & $+2,908$ \\
\hline \multicolumn{3}{|c|}{ Present value at $6 \%$} & $\ldots$ & $\ldots$ & $\ldots$ & $\$ 52,600$ & $\$ 19,600$ \\
\hline \multicolumn{3}{|c|}{ Internal rate of return } & $\ldots$ & ....... & , nam & $19.4 \%$ & $11.8 \%$ \\
\hline \multicolumn{6}{|c|}{ Present value/Present value of costs } & 4.2 & 1.5 \\
\hline
\end{tabular}

The effect of tax (as measured by comparing the national point of view with the individual point of view) is more severe than for dairy farmers because the sheep farmers had higher incomes before development started and made greater final gains per farmer after development was complete.

\section{land Development Case Histories}

Only two case histories of State Land Development in $\mathrm{N}$ orthland were analysed, as, on some blocks, the methods used have since been superseded by improved methods. To obtain a result comparable in terms of technical expertize with the other farms studied, the development of two of the most successful Lands and Survey blocks was examined.

The main procedure for development was to burn, fence, oversow and topdress heavily with lime and superphosphate from the air. Each paddock was stocked heavily with cattle and wethers to eat and trample regrowth. The paddocks take about 5 years to reach 3 to 5.5 ewe equivalents per acre under station management. However, a major part of the cost of this development is the houses, buildings and roads needed. These are the expensive overhead costs of development.

The average financial results from the two land development case studies are shown in Table 6. 
VALUE OF PASTORAL DEVELOPMENT

TABLE 6: MEAN LAND DEVELOPMENT RESULTS $(n=2)$

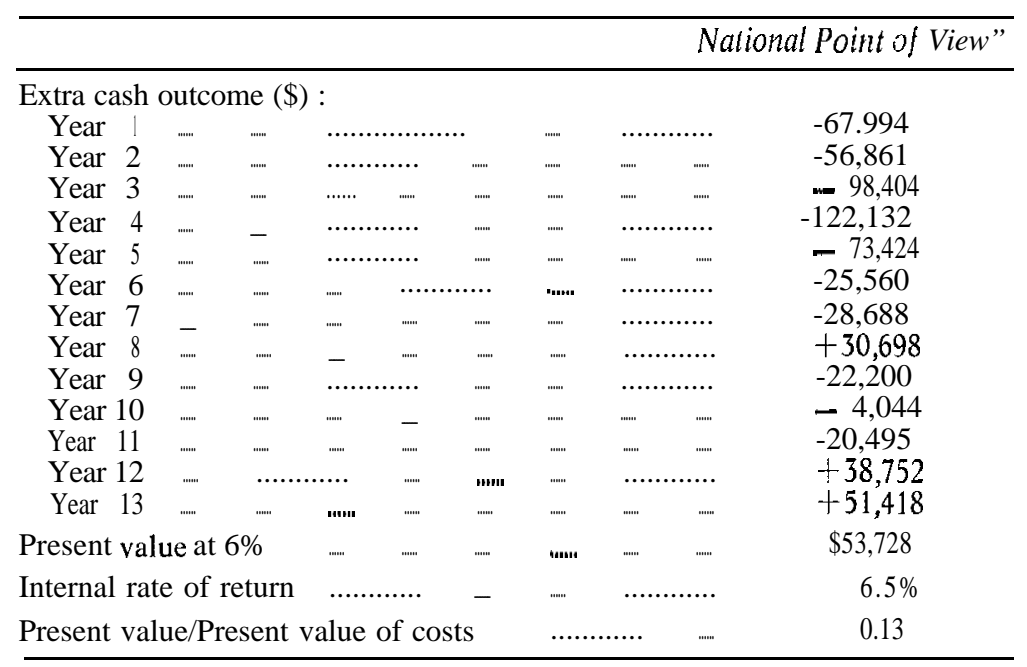

$*$ Tax considerations are not relevant where the development is carried out by government departments. Hence, the figures are shown from the nation's point of view.

\section{UNIT CASH FLOWS}

The results presented so far have been on a per-farm basis. Over the past few months, a method has been devised which extracts from the aggregate flow of costs and benefits of all farms the cash flow per ewe equivalent added. This method provides a best estimate of the costs and benefits of putting on an additional ewe equivalent in Northland." Unit cash flows have been extracted from the sheep farms' and the dairy farms' data separately. Only the national viewpoint has been considered. The internal rates of return of these units are the same as the rates for the aggregate data shown in Tables 3 and 5 . The present values of the unit cash flows for sheep and dairy are directly comparable.

The unit cash flows, their present values, internal rates of return and value/ cost ratios are shown in Table 7.

The interesting aspect of these data is that it appears to cost about $\$ 20$ to add a ewe equivalent in Northland whether it is on a sheep farm or a dairy farm. This figure is very close to the budgeted value published by the Agricul-

*The method was devised by the writers in association with G. R. Cleland. 
TABLE 7: UNIT CASH FLOWS

\begin{tabular}{|c|c|c|c|c|c|c|c|c|c|}
\hline \multirow{2}{*}{\multicolumn{3}{|c|}{ Unit cash flow (\$): }} & \multirow[b]{3}{*}{....... } & \multirow[b]{3}{*}{...."' } & \multirow{3}{*}{\multicolumn{2}{|c|}{.............. }} & \multicolumn{3}{|c|}{$\begin{array}{cc}\text { Dairy } & \text { Sheep } \\
\text { Development } & \text { Development }\end{array}$} \\
\hline & & & & & & & & & \\
\hline Year 1 & & & & & & & .".." & - 19.0 & -19.4 \\
\hline Year 2 & & ..... & ... & ..... & ............ & & .... & 11.6 & 4.6 \\
\hline Year 3 & $\ldots$ &... & $\ldots$ & $\ldots$ & ............ & & 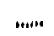 & 8.2 & 7.3 \\
\hline Year $\geqslant 4$ & & .... & $\ldots$ & ........ & & $\ldots$ & $\ldots$ & 11.2 & 3.2 \\
\hline \multicolumn{7}{|c|}{ Present value per ewe equivalent added ...... } & mm & $\$ 155.8$ & 36.1 \\
\hline \multicolumn{7}{|c|}{ Internal rate of return } & ."n!" & $56.1 \%$ & $20.6 \%$ \\
\hline \multicolumn{7}{|c|}{ Present value/Present value of cosis } & $\ldots$ & 8.7 & 2.0 \\
\hline
\end{tabular}

tural Development Conference and calculated by N. G. Gow. The unit cash flows are most useful for estimating the national cost of development. The net value of the benefits from adding a dairy ewe equivalent unit is four times greater than that from adding a sheep ewe equivalent.

\section{IMPLICATIONS OF THE RESULTS}

These results contain information of value both to individual farmers and to the nation.

\section{The Individual Viewpoint}

The present values of both sheep and dairy development are positive. The high internal rates of return suggest that even those who discount future gains severely will find that development is worth while. This information should encourage those farmers who wish to develop their farms but are uncertain about the financial implications and those who are considering bringing capital into the area for buying land.

However, the fact that a course of action has a positive value is one thing. Its feasibility is another. To assist farm advisory officers in advising their farming clients, two computer programmes, under the code name of "COPE", have been developed. These programmes, using estimates provided by the users and farm group data from projects such as these, do all the arithmetic of developing budgeting.

National Viewpoint

Ideally, similar data for both farm and non-farm projects in New Zealand should be available for comparison. However, we will take a sub-optimization approach and con- 
sider only these farming alternatives, given the present resources for N orthland.

\section{Land Development}

The barely positive present value from the national point of view for the two land development blocks is very much in line with other studies made at Lincoln College. Even with the best technology, the lagged results and the overhead cost of buildings and roads make land development a proposition of dubious economic value. Probably the best course for the Lands and the Maori A ffairs Departments to follow would be to intensify their farming operation on the land they have already brought in -eventually selling it to large-scale farming companies aiming at intensive production. Some of the blocks now planned for dairying might be suitable for 700 to 1,000 -cow dairy farms of the Wairarapa type. However, most of the blocks are sheep country. These, too, could be developed intensively as large company farms, and the heavy capital cost of subdivision into small one-man farms avoided. Lands and Survey Department would then become farm developers rather than land developers, making a higher contribution to $\mathrm{N} \mathrm{ew}$ Zealand as a consequence. If this change reduced their capital requirements, this money could be reallocated to farmers for development loans.

\section{Dairy Farm Development}

Results suggest that priority should be given to this industry, as dairy farms ranked highest on the present value/ cost ratio (30.7) and had four times the per ewe equivalent present value. Only five of the farms had negative present values at $6 \%$ rate of interest when the price of butterfat was reduced by $5 \mathrm{c}$ a lb. The internal rate of return was still $24 \%$ from the individual point of view. Consequently, despite rumblings of future uncertainty in dairy markets, it appears that the economic value of the margin from dairy development will still rank high if prices fall.

It is recommended that advisory services concentrate their advice to dairy farmers, and that priority be given to development lending to them through the State Advances Corporation, Marginal Lands Board and Maori Affairs Department. However, it is appreciated that money must be lent only to those who have the attributes for farming and a much closer co-ordination of advisory work with lending institutions appears desirable. 


\section{Sheep Farm Development}

Sheep farm development also has a positive present value, though its present value/ cost ratio is less than dairy farming - a not unexpected finding. At 22 cents net for wool, three of the $\mathbf{1 7}$ cases have negative present values at a $6 \%$ rate of interest and the internal rate of return from the individual point of view sinks from $11.8 \%$ to $9.8 \%$.

While it is not possible to separate out the effects of sheep and beef activities from the data, at present prices Northland sheep farmers would be wise to expand beef production, particularly dairy beef.

Sheep farming should be encouraged in Northland though not given top priority by government institutions.

Finally, planning for development in New Zealand must be done on a project by project basis, rather than on a sector by sector basis, because of the wide variation in value which probably exists within sectors. Probably there is a wide variation in value between projects within secondary industry, just as has been found between projects within the agricultural sector in Northland - ranging from extremely valuable dairy development to borderline land development.

\section{REFERENCE}

Galbraith, J. K. 1966: The Non-potable Scotch. Pelican.

\section{APPENDIX}

\section{DETAILS OF METHOD}

\section{A 1.1 M Odel of Outcome from the National Point of View}

This is given by

$$
O_{\mathrm{j}} \underset{\mathrm{i}=1}{m} I_{\mathrm{ij}}, P_{\mathrm{i}}-\mathrm{C}
$$

where $O_{j}$ is the cash outcome for New Zealand in the $j^{\text {th }}$ year,

$I_{i j}$ is the number of input or output items (bought or sold) in the $i^{\text {th }}$ class $(1,2, \ldots, i, \ldots, m)$ in the $i^{\text {th }}$ year. Thus, in the third year, a farmer may have sold $20,000 \mathrm{lb}$ of butterfat and bought amongst other things 25 tons of fertilizer. An input item such as fertilizer has a negative sign.

$P_{\mathrm{i}}$ is the price of the $i^{\text {th }}$ input or output per unit.

$C_{\mathrm{i}}$ is the aggregate cost of capital items.

This model uses constant prices over all years for the items bought and sold. This differs from historical reality in that prices in fact varied. However, unless prices are held constant, it is impossible to measure the influence of development on the $O_{j}$ s. 
Lack of data makes it difficult to itemize all the $I_{\mathrm{i} i}$ and the analyst is left with a residual of farm expenses, $-I_{\mathrm{mj}}$, which he multiplies by a price $\left(P_{\mathrm{m}}\right)$ of $£ 1.0$. These residual expenses and other variables expressed in cash terms were adjusted for changes in price levels over the years by using a price index for farm costs.

\section{Al.2 Model of Outcome from Individual Point of VieW}

To arrive at the cash outcome from the individual point of view, it is first necessary to calculate the outcome from the Inland Revenue Department's point of view.

Equation (2) models the essential elements of farm accounting to deterinine assessable income.

$X_{\mathrm{j}}=\sum_{i=1}^{m} I_{\mathrm{ij}} \cdot P_{\mathrm{i}}-R-D_{\mathrm{j}}-S$

where $X_{j}$ is the assessable income in the $j^{\text {th }}$ year

$R$ is the interest paid on mortgages

$D_{\mathrm{j}}$ is the depreciation allowance in the $j^{\text {th }}$ year

$S_{\mathrm{j}}$ is the change in stock values during the $j^{\text {th }}$ year.

Taxation paid is a function of $X_{\mathrm{j}}$ and exemptions which in turn depend on tax code, insurances, etc.

Equation (3) models the cash outcome from the individual point of view.

$\mathrm{O}_{\mathrm{j}}^{\prime} \underset{i=1}{m} I_{\mathrm{ij}} \cdot P_{\mathrm{i}}-\mathrm{R}-T_{\mathrm{j}}-C_{\mathrm{j}}$

where $O_{j}^{\prime}$ is the cash outcome from the individual point of view in the $j^{\text {th }}$ year, and $T_{\mathrm{j}}$ is the tax paid.

The technique of analysis answers this question: If the project was repeated again using the same items of input and giving the same output items, what would be the cash outcome if the items are valued at the prices that can be expected in the future?

\section{A2.0 Valuation of The OUtcome}

A marginal approach was adopted to determine the outcome of development, calculating the additional net costs of returns from development. $\mathrm{O}_{1}$ is the cash outcome before development started, $\mathrm{O}_{2}, \mathrm{O}_{3}, \ldots \mathrm{O}_{1}$ are the outcomes during development and $O_{n}$ the outcome after development is completed. Then the cash margin from development is $O_{2}-O_{1}, O_{3}-O_{1}$, $O_{j}-O_{1}$, in the first, second and $j^{t \text { th }}-1$ year of development, respectively The cash margin from development after development is completed is $\mathbf{O}_{n}-\mathbf{O}_{1}$.

Normal discounting procedures were used to allow for time to give these measures of the value of the margin from development: present value to internal rate of return, and present value to present value of costs ratio.

\section{A2.1 The Present Value}

This is a useful measure when deciding whether or not a project has a positive value and hence whether it is worth executing given that the 
resources are available to put it into operation. If a project has a negative expected present value it should not be executed.

$P=\sum_{j=2}^{n-1}\left[\frac{O_{j}-O_{1}}{(1+r)^{(j-1)}}\right]+\left(\frac{O_{\mathrm{n}}-O_{1}}{r}\right) /(1+r)^{(\mathrm{n}-2)}$

where $P$ is the present value of the cash margin from development, and $\mathbf{r}$ is the rate of interest as a proportion.

The nresent value has one maior drawback-it assumes that a rate of interest-of $\mathbf{r}$ can be used as a measure of the utility and disutility of cash outcomes for the decision-maker.

\section{A2.2 The Internal Rate of Return}

This is another useful measure. It is the value for $\mathbf{r}$ which makes $\boldsymbol{P}$ (in equation (4)) equal to zero. It is useful in break-even analyses for those decision-makers who are unsure about their utility functions. Thus, if a project has an internal rate of return of $10 \%$, a decision-maker may say, "I am sure I discount at a lower rate than this, so the present value of the project must be positive."**

\section{A2.3 Present Value/Present Value Cost Ratio}

This is a measure for assigning priorities to independent projects when a decision-maker wishes to maximize the present value of the sum of all projects selected but when he is constrained by cost. He ranks the projects in order of this ratio and selects down the list until the cumulative cost equals the budget constraint.

The three methods of valuing the cash outcomes are not substitutes. Each has its use, depending on the context of the decision.

* This statement is usually correct in that in practice the present value is a monotomically decreasing function of $\mathbf{r}$. However, it is possible to create examples of cash flows which are not monotomically decreasing functions of $\mathbf{r}$ and for which the above statement in inverted commas would not (necessarily) be true.

\section{DISCUSSION}

Does $\mathrm{Mr}$ McArthur think his conclusions are sw eeping in view of the fact that he selected successful results, ignoring, perhaps, cases where the technique of extra fertilizer and stock had been used, but had not achieved a response?

A. T. G. McArthur: The conclusion that dairy development is more profitable than sheep farm development, and that the latter would, in turn, rank ahead of land development, is a comparative statement. Random samples of a population of developing farms from each class could not be obtained. Comparing the best in each class has an element of subjectivity in it which we recognize, but the differences in economic value are so large that it is most unlikely that our conclusion is confounded by bias in farm selection. 
If it is a fact that the grassland potential in New Zealand is higher than current herds, would it not be betfer to channel development info the better class of land?

Mr McArthur: Yes, to generalize our results still further, I suspect that this is so. It is on the better land that all the facilities are available for raising stock numbers without incurring high capital costs like roads and houses. Higher revenue-earning kinds of stock can be carried on the better land and transportation costs are less because the poorer land is usually further away from ports. Further, the responses on the good land are usually more rapid, giving it an economic advantage.

I consider your remarks about the Lands and Survey Department ill advised. If your advice were followed generally, development in the South Island might cease and all development might shift to Auckland.

Mr MCAthur: This is a technical and scientific conference. If I thought it was in the national interest to follow a particular course of action, I would say so regardless of parochial interest. I am not criticising the Lands and Survey Department. It has done a magnificent job. I am saying that land development (public or private) does not have the same economic value as farm development. This is what one would expect to find for the reasons just outlined.

K. T. SANDERson: When we have reached 14 ewe equivalents per acre on our better' country, then it may be worth while to develop the poorer country.

\section{Are there not fringe benefits from land development by the Lands and Survey Department that you have overlooked? The blocks show farmers what can be done.}

Mr McArthur: I agree the blocks do have an extension effect but it must also be remembered that the 32 dairy farmers and 18 sheep farmers have also had an extension effect on their neighbours. In general, other farmers are more impressed by the efforts of people like themselves than by the operations of the State. 